\title{
An electrophoretic investigation of mammalian spermatid-specific nuclear proteins
}

\author{
Maryvonne Lanneau and M. Loir \\ I.N.R.A., Station de Physiologie de la Reproduction, 37380 Nouzilly, France
}

\begin{abstract}
Summary. Using standardized methods for protein extraction and analysis, the testes of rams, bulls, goats, boars, stallions, rats, cats, hedgehogs, European mink and ferrets were examined for basic spermatid nucleoproteins by electrophoresis. The results suggest that differences exist in the total number of these proteins as well as in the number and amount of the cross-linked cystein-containing proteins. These differences appear to be more family-specific than species-specific.
\end{abstract}

\section{Introduction}

Although the primary structure of several mammalian basic nuclear sperm proteins (BNSP, also named protamine) has been described, the changes in the nuclear proteins of spermatids have only been biochemically investigated in the rat (Platz, Grimes, Meistrich \& Hnilica, 1975; Grimes, Platz, Meistrich \& Hnilica, 1975; Grimes, Meistrich, Platz \& Hnilica, 1977), the ram (Loir \& Lanneau, 1978a, b) and the mouse (Geremia, Goldberg \& Bruce, 1976; Bouvier, 1977).

In rats and rams, histones leave the chromatin at specific stages of spermatid maturation, before being replaced by the basic sperm protein. During this replacement process, low molecular weight basic proteins, which are mostly spermatid-specific, are present in the nuclei. However, there are striking differences between these spermatid proteins in the rat and in the ram. Indeed, only $3\left(\mathrm{TP}, \mathrm{TP}_{2}, \mathrm{TP}_{3}\right.$ ) have been identified and analysed in the rat while 8 such proteins have been found in the ram. This difference could result from the techniques used. For instance, the numerous ram protein fractions could be due to proteolysis, or to unreduced oligomers or mixed disulphides. Evidence presented elsewhere (Loir \& Lanneau, 1978b) makes this seem unlikely. Since differences have already been demonstrated in the primary structure of 8 mammalian protamines (Coelingh et al., 1972; Kistler, Geroch \& Williams-Ashman, 1973; Monfoort, Schiphof, Rozijn \& Steyn-Parvé, 1973; Bellvé, Anderson \& Hanley-Bowdoin, 1975; Calvin, 1976; Balhorn, Gledhill \& Wyrobek, 1977; Tobita, Namoto, Tsutsumi, Nakano \& Ando, 1979), it is more probable that species-specific differences also exist in mammalian spermatid proteins.

In this study, we have conducted a comparative electrophoretic investigation of the basic spermatid proteins in 11 mammals belonging to 7 different zoological families.

\section{Materials and Methods}

\section{Animals}

Testes of adult animals were used either immediately after castration or after freezing and storage at $-20^{\circ} \mathrm{C}$. In rams, boars and goats, no significant differences have been detected between fresh and frozen testes. 
At least 10 rams (Ovis aries), 3 goats (Capra hircus) and 4 bulls (Bos taurus) were used from the Family Bovidae; there were 5 domestic boars (Sus scrofa) and 2 wild boars ( $S$. scrofa) (F. Suidae); 2 stallions (Equus caballus) (F. Equidae); 105 Wistar rats (Rattus norvegicus) (F. Muridae); 4 hedgehogs (Erinaceus europaeus) obtained in the non-breeding and the breeding season (F. Erinaceidae); 2 European mink (Mustela lutreola), 3 ferrets (Mustela furo) both in the breeding and the non-breeding season (F. Mustelidae); and 4 cats (Felis catus) (F. Felidae). Domestic animals and rats were reared at I.N.R.A., Nouzilly. Testes of wild boars, hedgehogs and mustelids were provided by C.E.B.A.S. (Chizé, France).

\section{Extraction of basic testicular proteins}

For each of these species, $3 \%$ trichloracetic acid (TCA)-soluble basic proteins in the testis were extracted according to Kistler et al. (1973). Testicular tissue, $20 \mathrm{~g}$ or the largest available amount, was homogenized in $0.4 \mathrm{~N}-\mathrm{H}_{2} \mathrm{SO}_{4}$. After centrifugation, proteins in the supernatant were fractionated by addition of TCA to a final concentration of $3 \%$. After a second centrifugation, $3 \%$ TCA-soluble proteins were precipitated by $20 \% \mathrm{TCA}$, then washed and dried, or dialysed against $0.01 \mathrm{~N}-\mathrm{HCl}$ and then freeze-dried. Heart, liver, uterus, pancreas and spleen tissues of sheep and pigs were subjected to a similar extraction as controls.

\section{Extraction of basic proteins from spermatid and sperm nuclei}

Populations of elongating and elongated spermatid nuclei were prepared from ram, bull and rat testicular tissues by treatment with $0.05 \%$ Triton X-100 after separation of spermatids by sedimentation at unit gravity (Loir \& Lanneau, 1978a).

When a sufficient amount of testis (about $20 \mathrm{~g}$ ) was available, i.e. from ram, goat, bull, boar, wild boar, rat and cat, sonication-resistant nuclei of non-round spermatids were prepared (Loir \& Lanneau, 1978a). After 1 or 2 purifications by centrifugation (1000 g, $30 \mathrm{~min}$ ) through 1.5 $M$-sucrose the populations of nuclei obtained from every species were as clean and pure as those previously characterized from ram preparations (Loir \& Lanneau, 1978a). Checks by phase-contrast microscopy showed that for every species the sonication-resistant nuclei corresponded only to elongated spermatid nuclei. For each of the species studied, sperm nuclei were prepared in the same way by sonication of spermatozoa from the cauda epididymidis or the ejaculate.

Acid-soluble basic proteins were extracted from the various spermatid and sperm nuclei populations with $0.4 \mathrm{~N}_{-} \mathrm{H}_{2} \mathrm{SO}_{4}$. After 3 acid extractions, which removed all the acid-soluble proteins, the cross-linked, cystein-containing basic proteins from the sonication-resistant spermatid nuclei and sperm nuclei were extracted by a reducing treatment (Loir \& Lanneau, 1978a). The nuclei were incubated for $4 \mathrm{~h}$ at $37^{\circ} \mathrm{C}$ with $0.28 \mathrm{M}-2$-mercaptoethanol, $1.2 \mathrm{M}-\mathrm{NaCl}$, $4 \mathrm{M}$-urea, $\mathrm{pH} 8 \cdot 5$. Then, iodoacetamide was added to a final concentration of $0.5 \mathrm{M}$ and, after $2 \mathrm{~h}$, DNA was precipitated by addition of $0.25 \mathrm{~N}-\mathrm{HCl}$, and removed by centrifugation. The supernatant was dialysed then freeze-dried.

\section{Electrophoretic analysis}

Protein extracts were analysed by electrophoresis on polyacrylamide gels containing 6.25 or 2.5 M-urea (the acetic acid-urea method of Panyim \& Chalkley, 1969). Cylindrical gels and $1 \mathrm{~mm}$ thick slab gels were used. Samples were preincubated for $2 \mathrm{~h}$ at $37^{\circ} \mathrm{C}$ with 0.5 M-2-mercaptoethanol. Gels were stained with amido-black and scanned with a Vernon densitometer. Relative mobilities $\left(R_{\mathrm{H} 4}\right)$ were measured for the major protein bands with reference to histone 4. For some samples, gels were stained for protein SH-groups with 5,5'-dithiobis(2-nitrobenzoic acid) (DTNB; Zelazowski, 1980). The various protein extracts of 
ram testicular tissue were also analysed by two-dimensional gel electrophoresis as described by Goldknopf \& Busch (1975).

\section{Results}

\section{Basic proteins from sperm nuclei}

After extraction by a reducing treatment of the sperm nuclei from ram, goat, bull, domestic boar, wild boar, rat and cat, only one prominent protein band was obtained, which corresponded to the basic nuclear sperm protein. In the domestic boar and the wild boar a smaller and slower additional band was present that we have named $\mathrm{V}$. It could correspond to a minor component of boar protamine which is known to be heterogeneous (Tobita et al., 1979).

\section{Basic proteins from non-round spermatid nuclei}

Typical electrophoregrams of basic proteins in sonication-resistant nuclei from 5 species are shown in Text-fig. 1. The bull and the wild boar are not shown because they differ only slightly from the ram and the goat, and from the boar respectively.



Text-fig. 1. Electrophoregrams on $2.5 \mathrm{M}$-urea gels of basic proteins from sonication-resistant (elongated) spermatid nuclei. Left: proteins extracted by $0.4 \mathrm{~N}-\mathrm{H}_{2} \mathrm{SO}_{4}$. Right: proteins extracted, after 3 acid extractions, by a reducing treatment $(0.28 \mathrm{M}$-2-mercaptoethanol). H1, H3, H4 = histones. Other proteins are referred to in the text. 
Although all the extracts were processed similarly, variations were observed between animals of one species, but usually this was in the relative amounts of the protein bands rather than in the occurrence and $R_{\mathrm{H} 4}$ value of the major protein bands.

Ram. In previous studies on the ram (Loir \& Lanneau, 1978a), only 6.25 M-urea gels were used. By using 2.5 M-urea gels (Text-fig. 1), the protein band previously named 13-15 and believed to correspond to the nuclear sperm protein in fact resolved into two bands. Compared to the sole protein extracted from sperm nuclei, it was the slower $\left(R_{\mathrm{H} 4}=1.74\right)$ of these two bands which was the basic nuclear protein and it has been designated ' $S$ ' according to the terminology used for the rat protein.

The faster band ( $\mathrm{T} ; R_{\mathrm{H} 4}=1.88$ ) was mostly acid-soluble (Text-figs 1 and 2). Analysis of nuclear proteins from spermatids separated by sedimentation at $1 \mathrm{~g}$ showed that this band was present simultaneously with the other known spermatid proteins. Because it is absent in spermatocyte nuclei (Loir \& Lanneau, 1978a) and absent in protein extracts of ovine organs, it is considered to be spermatid-specific. Its ability to be stained by DTNB and the fact that an additional amount of it is extracted after a reducing treatment (Text-fig. 1) suggested that this protein band should contain cystein, thus differing from protein TP in the rat.

Goat, bull, boar, wild boar, rat and cat. Analysis of sonication-resistant nuclei from these animals showed that 2 bands with $R_{\mathrm{H} 4}$ values roughly similar to those of $\mathrm{T}$ and $\mathrm{S}$ in the ram were present in acid extracts analysed on $2.5 \mathrm{M}$-urea gels. On $6.25 \mathrm{M}$-urea gels, band $\mathrm{T}$ had the same $R_{\mathrm{H} 4}$ value as band $\mathrm{S}$. For each species, it was the slowest of the two bands (S) which corresponded to the nuclear sperm protein extracted from spermatozoa. The fastest band, which in the bull and the boar could be stained by DTNB, was named T. In all species studied, including the ram, protein $S$ was virtually insoluble in acid, i.e. it was absent in $3 \%$ TCA-soluble testicular protein extracts and in acid nuclear extracts of spermatids separated at $1 \mathrm{~g}(2.5 \mathrm{M}$-urea gels). Sonication could, however, render band $\mathrm{S}$ partly acid-soluble as shown previously for the rat (Grimes et al., 1975).

The patterns of acid-soluble proteins and of 2-mercaptoethanol-extracted proteins from sonication-resistant nuclei from goats (Text-fig. 1) and bulls were similar to those obtained in the ram. In the bull, there was a smaller amount of protein band 2-3 in acid extracts of sonication-resistant and of non-round spermatid nuclei (Text-fig. 3). For a given protein band, the differences in $R_{\mathrm{H} 4}$ values between species were of the same magnitude as individual variations. It is therefore difficult to say whether slight differences exist in the $R_{\mathrm{H} 4}$ values between the 3 species; the mean $R_{\mathrm{H} 4}$ values for the major spermatid proteins ( $2.5 \mathrm{M}$-urea gels) of bulls, rams and goats were 0.88 for band $P_{1} ; 1.12$ for band $2-3 ; 1.37$ for band 7 and 1.88 for band $T$.

Domestic and wild boars display identical patterns of acid-soluble proteins on one hand and of 2-mercaptoethanol-extracted proteins (Text-fig. 1) on the other. The common acid-soluble protein differed from that of the bovids by the presence of 2 major bands between histone 4 $\left(\mathrm{H}_{4}\right)$ and band $\mathrm{S}$, named $\alpha\left(R_{\mathrm{H} 4}=1 \cdot 18\right)$ and $\beta\left(R_{\mathrm{H} 4}=1 \cdot 26\right)$, and 2 minor bands $\gamma$ and $\delta$. The mobilities of proteins $S$ and $T$ were greater than those in bovids $\left(R_{\mathrm{H}_{4}}=1.84\right.$ and 1.99 respectively) while that of band $\mathrm{P}_{1}$ was identical. Compared to the results for bovids, a smallar amount of spermatid proteins was extracted after the reducing treatment. In 2-mercaptoethanol extracts of spermatids (Text-fig. 1) a protein band co-migrates with the minor sperm protein $\mathrm{V}$.

In the rat, the results (Text-figs 1 and 3) were similar to those obtained by Grimes et al. (1975, 1977). However, in our hands, a smaller amount of $S$ was rendered acid-soluble by sonication and histones were still detectable in sonication-resistant nuclei. This could have resulted from a difference in the efficiency of sonication. The pattern of 2-mercaptoethanol-extracted proteins (Text-fig. 1) is in agreement with the known absence of cystein in protein TP, which cannot be stained by DTNB, and the presence of this amino-acid in $\mathrm{TP}_{2}$ and $\mathrm{TP}_{3}$ (Grimes et al., 1977), which can be stained by DTNB.

In the cat (Text-fig. 1), in addition to small amounts of histones still present in sonication-resistant nuclei and to an acid-soluble part of $S$, only two proteins were consistently 
extracted by acid. One, named T, was coincident with TP in the rat $\left(R_{\mathrm{H} 4}=1.94\right)$, and the other, named $\mathrm{A}$, was coincident with $\mathrm{TP}_{2}$. Protein $\mathrm{S}\left(R_{\mathrm{H} 4}=1.88\right)$ was the main protein extracted after a reducing treatment. The sperm protein in the cat was the fastest studied; because protein bands $\mathrm{S}$ and $\mathrm{T}$ have broadly similar $R_{\mathrm{H} 4}$ values it could not be determined whether an additional amount of $\mathrm{T}$ was extracted after reduction.

\section{TCA-soluble testicular proteins}

For the 11 species studied, 3\% TCA-soluble testicular proteins were prepared and analysed. Such extracts (Text-fig. 2) contained mainly histone 1 and several faster proteins. A comparison of the testicular protein patterns with protein patterns from spermatid nuclei (Text-figs 1 and 3 ) reveals that the major protein bands (with one exception: protein 12) displaying $R_{\mathrm{H} 4}$ values higher than that of histone 4 corresponded to spermatid proteins. This view is supported by two observations: (1) these bands were absent in extracts from various organs in the ram and in



Text-fig. 2. Electrophoregrams on $6.25 \mathrm{M}$-urea gels of $3 \%$ TCA-soluble basic testicular proteins. Hedgehog-1 = in breeding season; hedgehog $2=$ in non-breeding season. See text for proteins illustrated. 


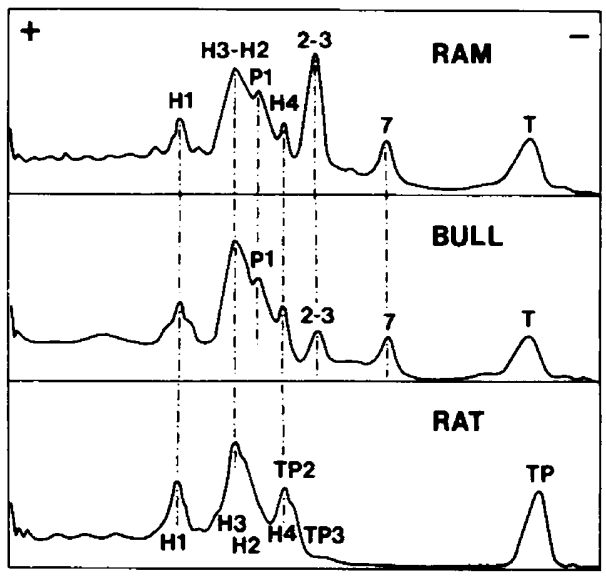

Text-fig. 3. Electrophoregrams on $6.25 \mathrm{M}$-urea gels of acid-soluble nuclear proteins from non-round spermatid populations obtained by sedimentation at $1 \mathrm{~g}$. Every population contained roughly the same proportion of elongating (sonication-sensitive) and elongated (sonicationresistant) spermatid nuclei. $\mathrm{H} 1, \mathrm{H} 2, \mathrm{H} 3, \mathrm{H} 4=$ histones. Other proteins referred to in the text.

the boar (in which only one protein band has an $R_{\mathrm{H} 4}$ near that of ram spermatid protein 2); (2) in the ram, these bands migrate on two-dimensional acrylamide gels as the corresponding spermatid proteins.

The presence of several protein bands not of spermatid nuclear origin between histone 1 and histone 4 masked any possible occurrence of spermatid proteins such as $P_{1}$. The 2 testicular proteins named $P_{2}$ and 12 (Text-fig. 2) were present in the ovine and porcine control organs but absent in purified spermatid nuclei.

Sonication-resistant nuclei of spermatids were not prepared for stallion, hedgehog, mink and ferret but the $3 \%$ TCA-soluble protein patterns provided some information on the spermatid proteins faster than histone 4 . In the stallion, there appeared to be 2 proteins with the same $R_{\mathrm{H} 4}$ values as the bovid proteins 2 and T. In the hedgehog (Text-fig. 2), 2 proteins were probably present but their mobilities were comparable with those of bovid proteins 7 and $T$. The link between these 2 proteins and the spermatids is confirmed by their absence in testes devoid of these cells during the non-breeding season (Text-fig. 2). In the mink and ferret there seemed to be no spermatid protein faster than histone 4 and it is not known whether one or more slower proteins (such as $\mathrm{P}_{1}$ ) are present.

\section{Discussion}

In the rat and in the ram, the stage of spermatid maturation at which the onset of sonication resistance occurs is known. This corresponds to the end of nuclear elongation which is coincident with the time when histones are nearly completely removed from chromatin. In the other animals studied, the corresponding maturation stage is unknown. Nevertheless, because the sonication-resistant nuclei appear to be elongated nuclei and contained very low amounts of histones (Text-fig. 1), we suggest that the acquisition of resistance to sonication reflects similar nucleoprotein changes and chromatin reorganization in the mammals studied.

In the rat and in the ram, the spermatid proteins are known to be present in the sonication-sensitive elongated nuclei as well as in the sonication-resistant elongated nuclei and all the spermatid proteins present in the first type of nuclei are also present in the second kind (compare Text-figs 1 and 3). If this is true of the other mammals studied, the analysis of proteins 
from sonication-resistant nuclei only does permit characterization of all the spermatid proteins present in one species.

When insufficient amounts of testis are available for the preparation of sonication-resistant nuclei, a suitable alternative is the extraction of 3\% TCA-soluble testicular proteins, which is also more rapidly carried out. Indeed, our results indicate that this method enables a check to be made for the presence of spermatid proteins faster than histone 4 . This procedure is very reliable if similar extracts are simultaneously prepared from 2 or 3 organs.

Our results establish unambiguously that a large between-species variation exists with respect to the basic proteins momentarily present in mammalian spermatid nuclei at the time of histone removal. However, these differences appear to be more family-specific than species-specific. Indeed, the 3 bovid species studied possess the same spermatid proteins with only slight quantitative variations and the 2 mustelids also displayed a similar protein pattern.

Protein $\mathrm{T}$ is absent only in mustelids and it could be the most ubiquitous spermatid protein in mammals. In all animals in which protein T or TP is present, there is a similar change in the $R_{\mathrm{H} 4}$ value when the urea molarity in the gels is reduced from 6.25 (at which value T/TP migrates with $\mathrm{S}$ ) to 2.5 (at this value it migrates faster than $\mathrm{S}$ ). Furthermore, in bovids, the boar and the rat, this protein has the same solubility in TCA, becoming insoluble at concentrations between 6 and $9 \%$ (unpublished data). It is therefore suggested that protein $\mathrm{T}$ is the same protein in all species. However, the patterns after 2-mercaptoethanol-extraction and the ability to be stained by DTNB indicate that protein $T$ appears to contain cystein, at least in the bovids, although this amino acid is absent in the rat protein TP. The $R_{\mathrm{H} 4}$ value of proteins T or TP shows variations between 1.88 (F. Bovidae) and 1.99 (F. Suidae). These differences in cystein content and in $R_{\mathrm{H} 4}$ value could reflect phylogenetic modifications in the primary structure of this spermatid protein. The occurrence of phylogenetic variations has been already demonstrated for the sperm protein primary structure in at least 8 mammals (Coelingh et al., 1972; Kistler et al., 1973; Monfoort et al., 1973; Bellvé et al., 1975; Calvin, 1976; Balhorn et al., 1977; Tobita et al., 1979). Even in one family (ram: Monfoort et al., 1973; bull: Coelingh et al., 1972) variations exist but they are less numerous than between phylogenetically distant species.

Concerning the other spermatid proteins, no data are presently available to check the correspondence of the various proteins in the different families. The fact that a protein band present in one or more species is seemingly absent in others may result from the existence of truly different proteins as well as from dramatic phylogenetic variations in the considered protein. Only the knowledge of the amino acid composition of the major spermatid proteins in various families will tell if one or more proteins are common to several mammals.

It has been proposed that the spermatid proteins of the rat (Grimes et al., 1977) and the ram (Loir \& Lanneau, 1978a) may be involved in the shaping and condensation of the spermatid nuclei. The cross-linking of the spermatid proteins by $-\mathrm{S}-\mathrm{S}-$ bridges could play an essential role in chromatin reorganization (Loir \& Courtens, 1979). Our results suggest that the spermatid nuclear changes do not need, depending on the species, as many acid-soluble proteins and as many cross-linked proteins as in bovids and in suids. Since in the rat the nuclear changes require only 3 spermatid proteins, it can be questioned whether all the proteins in animals with more than 3 proteins play a necessary role. The discovery of any animals which possess only one or no spermatid protein would also be of interest for the possible evolutionary significance of the variation in spermatid and sperm nuclear proteins.

The structural pattern of chromatin condensation has been studied in 7 mammals with sickle-shaped or flattened-ovoid shaped sperm nuclei (Courtens \& Loir, 1975, 1981). Similarities were again observed amongst bovids (ram, bull and goat) while differences exist between these and the 4 other species (boar, mouse, rat, stallion) which each had an individual pattern. Further comparative biochemical and ultrastructural investigations on spermatid proteins may provide clues to the structure-function relationships in nuclear protein changes during mammalian spermiogenesis. 
This work was supported by a grant from Délégation Générale à la Recherche Scientifique et Technique (D.G.R.S.T. 79-7-1211). We thank Dr L. Boissin, Dr J. Boissin, Dr M. Saboureau, Dr R. Mauget (C.E.B.A.S.-C.N.R.S., Chizé) and Dr A. Aumaitre (I.N.R.A., Jouy-en-Josas) for providing testes of wild animals; and Dr J. Williams for help with the manuscript.

\section{References}

Balhorn, R., Gledhill, B.L. \& Wyrobek, A.J. (1977) Mouse sperm chromatin proteins: quantitative isolation and partial characterization. Biochemistry, N.Y. 16, 4074-4080.

Bellvé, A.R., Anderson, E. \& Hanley-Bowdoin, L. (1975) Synthesis and amino acid composition of basic proteins in mammalian sperm nuclei. Devl Biol. 47, 349-365.

Bouvier, D. (1977) Chemical aspects of histone acetylation and replacement in mouse spermatids at different stages of maturation. Cytobiologie 15, 420-437.

Calvin, H.l. (1976) Comparative analysis of the nuclear basic proteins in rat, human, guinea pig, mouse and rabbit spermatozoa. Biochim. Biophys. Acta 434, 377-389.

Coelingh, J. P., Monfoort, C. H., Rozijn, T.H., Geversleuven, J.A., Schipof, R., Steyn-Parvé, E.P., Braunitzer, G., Schrank, B. \& Ruhfus, A. (1972) The complete amino acid sequence of the basic nuclear protein of bull spermatozoa. Biochim. Biophys. Acta $285,1-14$.

Courtens, J.L. \& Loir, M. (1975) Mise en évidence par cytochimie ultrastructurale de la migration des histones riches en lysine du cours de la spermiogenèse du bélier. J. Microscopie Biol. Cell 24, 249-258.

Courtens, J.L. \& Loir, M. (1981) A cytochemical study of nuclear changes in boar, bull, goat, mouse, rat and stallion spermatids. J. Ultrastruct. Res. 74, 327-340.

Geremia, R., Goldberg, R.B. \& Bruce, W.R. (1976) Kinetics of histone and protamine synthesis during meiosis and spermiogenesis in the mouse. Andrologia 8, 147-156.

Goldknopf, I.L. \& Busch, M. (1975) Electrophoresis of acid soluble proteins from rat liver and polysomes on large two-dimensional polyacrylamide gels. Physiol. Chem. Physics 7, 23-30.
Grimes, S.R., Platz, R.D., Meistrich, M.L \& Hnilica, L.S. (1975) Partial characterization of a new basic nuclear protein from rat testis elongated spermatids. Biochem. Biophys. Res. Commun. 67, 182-189.

Grimes, S.R., Meistrich, M.L., Platz, R.D. \& Hnilica, L.S. (1977) Nuclear protein transitions in rat testis spermatids. Expl Cell. Res. 110, 31-39.

Kistler, W.S., Geroch, M.E. \& Williams-Ashman, M.G. (1973) Specific basic proteins from mammalian testes. J. biol. Chem. 248, 4532-4543.

Loir, M. \& Courtens, J.L. (1979) Nuclear reorganization in ram spermatids. J. Ultrastruct. Res. 67, 309-324.

Loir, M. \& Lanneau, M. (1978a) Transformation of ram spermatid chromatin. Expl Cell. Res, 115, 231-243.

Loir, M. \& Lanneau, M. (1978b) Partial characterization of ram spermatidal basic nuclear proteins. Biochem. Biophys. Res. Commun. 80, 975-982.

Monfoort, C.H., Schiphof, R., Rozijn, T.H. \& SteynParvé, E.P. (1973) Amino acid composition and carboxyl-terminal structure of some basic chromosomal proteins of mammalian spermatozoa. Biochim. Biophys. Acta 322, 173-177.

Panyim, S. \& Chalkley, R. (1969) High resolution acrylamide gel electrophoresis of histones. Archs Biochem. Biophys. 130, 337-346.

Platz, R.D., Grimes, S.R., Meistrich, M.L. \& Hnilica, L.S. (1975) Changes in nuclear proteins of rat testis cells separated by velocity sedimentation. $J$. biol. Chem. 550, 5791-5800.

Tobita, T., Nomoto, M., Tsutsumi, H., Nakano, M. \& Ando, T. (1979) The complete amino acid sequence of a major boar protamine. Proc. IIth Int. Congr. Biochem., Toronto, p. 46, Abstr. 01-7-H1.

Zelazowski, A.J. (1980) Methods of selective staining of polyacrylamide gels for -SH groups and cadmium. Analyt. Biochem. 103, 307-312.

Received 3 July 1981 